\title{
DIVERSITY OF SNAKE RESCUED FROM RESIDENTIAL AREAS IN GREATER JAKARTA METROPOLITAN AREA, INDONESIA
}

\author{
Ira KHOERUNISA, MirZA D. KUSRINI ${ }^{*}$, AND ANI MARDiASTUTI \\ Department of Forest Resources Conservation and Ecotourism, Faculty of Forestry and Environment, IPB \\ University,Bogor, 16680, Indonesia \\ *Email: mirza_kusrini@yahoo.com
}

Accepted March 16, 2021 / Approved December 23, 2021

\begin{abstract}
Development and habitat loss in Greater Jakarta Metropolitan Area affected snakes and forced them to adapt in urban areas. Snakes in residential areas might increase encounter rate with humans which lead to human-snake conflict. The objectives of this research were to identify the diversity of snakes in residential areas based on rescue effort and to documents effort of those organizations on how to mitigate human-snake conflict through snake relocation. From 2015-2019, 37 snake species were reported found around residential areas in Jakarta Metropolitan Area. Javan spitting cobra Naja sputatrix and reticulated python Malayopython reticulatus are the most encountered snakes in residential areas. Jakarta has the highest total encounter of snakes compared to other area but Bogor has the highest diversity of snake species. Snake found in residential areas are sometimes "rescued" by snake reptile enthusiasts who formed a group. Most of these group does not have standard operating procedure when rescuing snake. Human-snake conflict can be mitigated by relocation of snakes, education, and translocation, although the impact of translocation should be evaluated further.
\end{abstract}

Key words: Jakarta Metropolitan Area, human-snake conflict, Urban area, snake rescue

\section{INTRODUCTION}

Although the population of reptile, including snake, are globally threatened because of various factors i.e. habitat loss and degradation and land conversion (Gibbons et al. 2000), some species of snakes are able to adapt in residential areas and often encountered by the residents. Report on the presence of snakes in residential areas mostly come from overseas i.e. in Africa (Reed \& Krysko 2013), Australia (Shine \& Koenig 2001) and India (Roshnath 2017). Despite almost no report on snakes in residential areas in Indonesia, Hartanto (2014) states that Javan spitting cobra (Naja sputatrix), Malayan pit viper (Calloselasma rhodostoma), and Oriental wolf snake (Lycodon capucinus) as the most common snakes around residential areas in Java Island. Mass media also often reports news about snakes encounters in residential area, such as the finding of Reticulated pythons (Malayopython reticulatus) that fell from the roof of a house in South Jakarta (Maulana 2019) or in the pipes of a residential area in Bekasi (Fakih 2019).

The appearance of snakes in residential area often makes people uneasy. According to Davies et al. (2004), compared to all species of animals in urban community, snakes are the most undesirable animals around the house. The existence of a biased perception from the public about snakes makes this animal difficult to get protection and conservation efforts (Ceríaco et al. 2012). As predators and prey in the food chain, the perception bias ignore the important role of snakes in the ecosystem. Food scraps and waste from anthropogenic activity can trigger the emergence of synanthropic animals such as birds and rats in settlements (McKinney 2008) which will become diet for snake.

The lack of public knowledge about snakes and their handling can lead to snakebite incidents. In various countries, to mitigate human-snake conflicts, there are volunteers who relocate snakes from residential areas, i.e. in India (Roshnath 2017) and Australia (Shine \& Koenig 2001). In Indonesia, some residents choose to ask for help from snake charmers/keeper or volunteers to move snakes. The existence of these volunteers is important, not only to help the community but also to record the types of snakes that are common in settlements. At present there are no systematic data or scientific publications showing the diversity of snakes that are most often found by residents in residential areas in Indonesia, especially in Jakarta, Bogor, Depok, Tangerang, and Bekasi (Greater Jakarta Metropolitan Areas) and communities' efforts to help mitigate conflicts between snakes and human. Information on the diversity of snake species around residential area will provide initial database for mitigate conflict between snake and humans in the future. This study aims to identify the diversity of snake species that are often encountered by residents in the Jakarta Metropolitan Areas and report local community efforts to mitigate human-snake conflict.

\section{RESEARCH METHOD}

Study was conducted from April to August 2019 in the Greater Jakarta Metropolitan Area (Jakarta, Bogor, Depok, Tangerang and Bekasi regions). Representatives 
from fourteen organizations which include 8 reptile enthusiast communities (Aspera Community, Sioux, Ciliwung Herpetarium, Sahabat Reptil Bekasi, Bogor Reptile Addicted, Tabu Indonesia, Indonesian Snake Wagleri, Kelompok Pemerhati Herpetofauna Himakova), one pest and termites control company in Bogor, and 5 fire departments (Bogor, Jakarta, Depok, Tangerang, and Bekasi) were interviewed to obtain data from the past 5 years.

We checked uploads regarding snake rescues from their official social media (Facebook and Instagram) and also conducted online searching from online news from January 2015 to August 2019 with area coverage in Jakarta, Bogor, Depok, Tangerang, and Bekasi. We recorded information on the time of encounter (date, month, year), location of the discovery (City/Regency, District, Village, place of discovery), scientific name, local name, data source, and other information considered important for each case. We double checked online news, to make sure that we did not record the same incidents.

We collected data on the number and composition of species found by residents in Greater Jakarta Metropolitan Areas in 2015-2019. Snakes were classified based on its envenomation using World Health Organization category as category one and two. Category one are common or widespread snakes that its venom will result in high morbidity, disability, or mortality. Category two species are snakes with venom capable of causing morbidity, disability, or death, or for which epidemiological or clinical data are missing or are less frequently implicated (WHO 2016; Longbottom et al. 2018). The first category usually given to all venomous snake from Elapidae, Viperidae and Colubridae. The second category usually given to snakes with mild local envenoming like Boiga, Ahaetulla, Cerberus and Enhydris (WHO 2016). Name of snake follows the Reptile Database (Uetz and Stylinou 2018).

To determine the efforts made by the communities and agencies in Greater Jakarta Metropolitan Areas in finding snakes we interviewed a person from each 10 organizations. Interviews were conducted in a structured manner to gather information regarding the number of snake and species rescued, background of snake rescue activities, snake rescue management, human resources involved in the rescue and the fate of snake after rescue.

\section{RESULT AND DISCUSSION}

\section{Species compositions and relative abundance}

There were 656 reports of snake encounters by communities in the Greater Jakarta Metropolitan Area within four and a half years (January 2015 - August 2019). Comparison with report of snake-human conflict in online news shows that data from interview is higher (Table 1).

Number of species reported is 37 species from 9 families, mostly Colubridae. Most common snake found are javan spitting cobra, Naja sputatrix (204 encounters; $31.1 \%$ ) and reticulated python, Malayopython reticulatus (177 encounters; 27\%). Similarly, the most widely reported species in online news are reticulated python and javan spitting cobra (Table 2). The next ten most common snakes were Ahaetulla prasina, Lycodon capucinus, Bungarus candidus, Dendrelaphis pictus, Coelognathus flavolineatus, C. radiatus, Ptyas korros, Cylindrophis ruffus. Bogor had the most diverse species compared to other regions, with 31 species, whereas the lowest diversity was in Bekasi region (13 species, Table 2).

Snakes were mostly concentrated in densely populated areas, especially Jakarta, South Tangerang, Depok, and Bogor City. Bogor Regency, Tangerang Regency, and Bekasi Regency are relatively sparsely distributed compared to urban areas. Jakarta had the most snake encounters (241 encounters) and dominated by reticulated python $(45.2 \%$, Table 2$)$. Bekasi has the lowest reported snake (65 encounters). Javan spitting cobra is the most widely reported species in the Tangerang region (55 individuals, 57.3\%) followed by Depok (51.2\%), Bogor (23.2\%), and Bekasi (35.4\%).

Table 1 Number of snake encounter reports in Greater Jakarta Metropolitan Areas from January 2019 until August 2019.

\begin{tabular}{lllllll}
\hline \multirow{2}{*}{ Sources } & \multicolumn{9}{c}{ Year } & \multicolumn{2}{c}{ Total } \\
\cline { 2 - 6 } & 2015 & 2016 & 2017 & 2018 & 2019 \\
\hline Organization database & 67 & 56 & 245 & 127 & 117 & 612 \\
Online news & 5 & 10 & 0 & 0 & 29 & 44 \\
\hline
\end{tabular}


Table 1 Snake species and percentage of reported by residents in Greater Jakarta residential area in 2015-2019 based on interview and online news sources. 1 = Jakarta , 2 = Bogor, 3 = Depok; 4 = Tangerang; 5 = Bekasi; Venom: $* *=$ Category $1,{ }^{*}=$ category $2($ WHO 2016$)$

\begin{tabular}{|c|c|c|c|c|c|c|}
\hline \multirow{2}{*}{ No } & \multirow{2}{*}{ Species } & \multicolumn{5}{|c|}{ Percentage } \\
\hline & & 1 & 2 & 3 & 4 & 5 \\
\hline & Colubridae & & & & & \\
\hline 1 & Ahaetulla mycterizans ${ }^{\#}(\mathrm{n}=4)$ & 0 & 0.6 & 0 & 3.1 & 0 \\
\hline 2 & Ahaetulla prasina ${ }^{\#}(\mathrm{n}=73)$ & 14.6 & 13.1 & 8.1 & 4.2 & 7.7 \\
\hline 3 & Boiga dendrophilla $a^{\#}(\mathrm{n}=1)$ & 0 & 0.6 & 0 & 0 & 0 \\
\hline 4 & Boiga multomaculata $(\mathrm{n}=1)$ & 0 & 0.6 & 0 & 0 & 0 \\
\hline 5 & Coelognathus flavolineatus $(\mathrm{n}=13)$ & 0 & 5.4 & 1.2 & 1 & 3.1 \\
\hline 6 & Coelognathus radiates $(\mathrm{n}=13)$ & 2.1 & 21.2 & 2.3 & 2.1 & 3.1 \\
\hline 7 & Dendrelaphis formosus $(\mathrm{n}=1)$ & 0 & 0.6 & 0 & 0 & 0 \\
\hline 8 & Dendrelaphis pictus $(\mathrm{n}=21)$ & 3.1 & 2.4 & 2.3 & 4.2 & 6.2 \\
\hline 9 & Dendrelaphis subocularis $(\mathrm{n}=1)$ & 0 & 0.6 & 0 & 0 & 0 \\
\hline 10 & Gonyosoma oxycephalum $(\mathrm{n}=4)$ & 0 & 2.4 & 0 & 0 & 0 \\
\hline 11 & Liopeltis tricolor $(\mathrm{n}=1)$ & 0 & 0.6 & 0 & 0 & 0 \\
\hline 12 & Lycodon capucinus $(\mathrm{n}=43)$ & 7.1 & 7.1 & 9.3 & 3.1 & 4.6 \\
\hline 13 & Oligodon octolineatus $(\mathrm{n}=5)$ & 0 & 0.6 & 2.3 & 2.1 & 0 \\
\hline 14 & Ptyas carinata $(\mathrm{n}=1)$ & 0 & 0.6 & 0 & 0 & 0 \\
\hline 15 & Ptyas korros $(\mathrm{n}=11)$ & 0.4 & 2.4 & 2.3 & 2.1 & 3.1 \\
\hline 16 & Ptyas mucosa $(\mathrm{n}=1)$ & 0.4 & 2.4 & 2.3 & 2.1 & 3.1 \\
\hline 17 & Rhabdophis subminiatus $(\mathrm{n}=3)$ & 0 & 1.8 & 0 & 0 & 0 \\
\hline 18 & Sibynophis geminatus $(\mathrm{n}=2)$ & 0.4 & 0.6 & 0 & 0 & 0 \\
\hline 19 & Xenochrophis piscator $^{\#}(\mathrm{n}=1)$ & 0 & 0 & 0 & 0 & 1.5 \\
\hline 20 & Xenochrophis trianguligerus ${ }^{\#}(\mathrm{n}=4)$ & 0.4 & 1.2 & 0 & 1 & 0 \\
\hline 21 & Xenochrophis melanzostus ${ }^{\#}(\mathrm{n}=2)$ & 0.8 & 0 & 0 & 0 & 0 \\
\hline \multirow[t]{2}{*}{22} & Xenochrophis vittatus $^{\#}(\mathrm{n}=1)$ & 0 & 1.8 & 2.3 & 0 & 0 \\
\hline & Cylindrophiidae & & & & & \\
\hline \multirow[t]{2}{*}{23} & Cylindrophis ruffus $(\mathrm{n}=10)$ & 1.7 & 3 & 0 & 0 & 1.5 \\
\hline & Elapidae $^{* *}$ & & & & & \\
\hline 24 & Bungarus candidus $(\mathrm{n}=24)$ & 2.5 & 6 & 1.2 & 6.3 & 1.5 \\
\hline 25 & Bungarus fasciatus $(\mathrm{n}=2)$ & 0 & 0.6 & 0 & 1 & 0 \\
\hline 26 & Bungarus flaviceps $(\mathrm{n}=1)$ & 0 & 0.6 & 0 & 0 & 0 \\
\hline 27 & Calliophis intestinalis $(\mathrm{n}=2)$ & 0 & 1.2 & 0 & 0 & 0 \\
\hline 28 & Naja sputatrix $(\mathrm{n}=204)$ & 18.4 & 23.2 & 51.2 & 57.3 & 35.4 \\
\hline \multirow[t]{2}{*}{29} & Ophiophagus hannah $(\mathrm{n}=4)$ & 0 & 0 & 1.2 & 3.1 & 0 \\
\hline & Homalopsidae\# & & & & & \\
\hline 30 & Enhydris enhydris ${ }^{\#}(\mathrm{n}=1)$ & 0.4 & 0 & 0 & 0 & 0 \\
\hline \multirow[t]{2}{*}{31} & Homalopsis buccata $(\mathrm{n}=9)$ & 1.7 & 1.2 & 1.2 & 1 & 1.5 \\
\hline & Pareatidae & & & & & \\
\hline \multirow[t]{2}{*}{32} & Pareas carinatus $(\mathrm{n}=5)$ & 0.4 & 1.8 & 1.2 & 0 & 0 \\
\hline & Pythonidae & & & & & \\
\hline \multirow[t]{2}{*}{33} & Malayopython reticulatus $(\mathrm{n}=177)$ & 45.2 & 16.7 & 14.1 & 8.3 & 29.2 \\
\hline & Viperidae $^{* *}$ & & & & & \\
\hline 34 & Calloselasma rhodostoma $(\mathrm{n}=3)$ & 0.4 & 1.2 & 0 & 0 & 0 \\
\hline
\end{tabular}




\begin{tabular}{lllllll}
\hline \multirow{2}{*}{ No } & \multirow{2}{*}{ Species } & \multicolumn{5}{c}{ Percentage } \\
\cline { 3 - 6 } & & 1 & 2 & 3 & 4 & 5 \\
\hline 35 & Trimeresurus albolabris $(\mathrm{n}=1)$ & 0 & 0.6 & 0 & 0 & 0 \\
36 & Trimeresurus puniceus $(\mathrm{n}=1)$ & 0 & 0.6 & 0 & 0 & 0 \\
& Xenopeltidae & & & & \\
37 & Xenopeltis unicolor $(\mathrm{n}=5)$ & 0 & 1.8 & 2.3 & 0 & 0 \\
\hline
\end{tabular}

Most snake encountered are non-venomous (n =314, 17 species) from family Colubridae, Cylindrophiidae, Pareatidae, Pythonidae, and Xenopeltidae; and dominated by reticulated python (56.4\%). However, category one snakes are also common $(n=245)$, dominated by javan spitting cobra $(83.3 \%)$. Encounters with category two were low ( $\mathrm{n}=97)$, dominated by Asian vine snake (75.3\%). Highest report of non-venomous and category two snakes is in Jakarta area. Tangerang has the highest reported of category one snake ( $\mathrm{n}=65$ ) but with the least number of non-venomous snakes $(n=22)$. Bekasi region, which includes the City and Regency of Bekasi had lowest encounter of category one and two snakes (Table 2).

Most report on snake encounters were recorded in 2017 ( $n=245$ reports), with lowest report in 2016 (66 reports). Only $10 \%$ of data had detailed record of time during snake encounter $(n=67)$. Most snake were found during night time including one before sunrise $(n=48), 39$ snake were encountered during the day, and 10 snakes were encountered in the morning. The finding of reticulated python varied $(n=30)$, mostly in culvert (8), water pipes (5), ceiling (4), in the yard (4) which include one carried by water flooding. They were also found in river banks, inside a shop, inside the toilet, behind table, crossing the road, in the barrel, around chicken cage, and coiling car battery. Javan spitting cobra $(n=13)$ were mostly found inside the house i.e. in the kitchen and bathroom (6), and outside such as in the garden or backyard (4), in the chicken coop (2) and among pile of garbage (1). Other species $(n=16)$ were mostly found around the yard, in the field, in the house or hiding between utensils, or were passing on the road.

Species reported in this result offered a snapshot of population and diversity of snake species in urban area. There is a possibility that the number of species is higher, because there are at least 49 species of snakes in Jakarta, Bogor, Depok, Tangerang, Bekasi (Greater Jakarta Metropolitan Area) (Rusli 2016). There are many factors that affect the result, such as limited access to snake rescue information, inconsistent and unstructured recording systems of the organizations, or people's perceptions and behaviour to snakes.

There are more species reported by organizations' than online news, which limited only two species, Javan spitting cobra ( $N$. sputatrix) and Reticulated python ( $M$. reticulatus). This is presumed because both species are considered dangerous by the community so it is more interesting to report on. Naja sputatrix is commonly known as a highly venomous snake with fatal bite. Meanwhile, Malayopython reticulatus is a large snake, which can wrap and swallow humans. Spectacular cases about pythons pouncing and swallowing humans, i.e. in Mamuju, West Sulawesi (Fajar 2018) and in Buton, Southeast Sulawesi (Neke 2019) has been viral in social media and can indirectly shape the public's perception that the snake is dangerous and terrorized humans. The results of evolution have associated snakes as danger signals so that encounters with snakes activate fear stimuli (Öhman \& Mineka 2003).

The three most common venomous species found are Javan spitting cobra and Malayan krait Bungarus candidus, all belong to the Elapidae family and possess neurotoxins that attack the nervous system, as well as cardiotoxins with cytotoxins in the Javan spitting cobra (Kumar et al. 2006). The javan spitting cobra is the most common species found in the city. The existence of $N$. sputatrix in residential areas might be caused by the abundance of prey in the area, such as small mammals, frogs, lizards, birds, and snakes. The population density of prey will be directly proportional to the number of predator population (McKinney 2008). Naja sputatrix is a generalist and opportunistic predator that will eat any prey, including other cobras (Maritz et al. 2018). Although number of Naja sputatrix encounters in this report could not be inferred as population, but it is reasonable to conclude that the abundance of javan cobra might be supported by lots of prey in the residential areas. The number of other venomous snakes found are mostly low, less than 5 incidents, but it also includes the king cobra Ophiophagus hannah. The species is mostly found in natural areas (Stuart et al. 2012), however it is also reported found in area near human settlements not only in Indonesia but also in India and Hong Kong (Shankar et al. 2013, Maulidi et al. 2020, Yue et al. 2019). The king cobra is also popular as pet snake, even in the city (Kusrini et al. 2020), thus making it possible that accidently loose snake from captivity to roam in highly urbanized areas.

The occurrence of other abundant snake, such as the reticulated python also showed the adaptability of the species to persist in urban area. Malayopython reticulatus naturally lives in tropical or deciduous forests, but they were known to live well in gardens and swamps, and other locations close to water, such as rivers and lakes (Stuart et al. 2018). It is not uncommon for the snake to be a suspect in the loss of cattle as it is known to prey on residents' livestock. This has the potential to trigger conflicts between snakes and humans. 
Changes in landscapes have negative impact on the environment, by changing the function of ecosystems and loss of habitat causing changes in the composition of wildlife communities and decrease of biodiversity (Gilbert 1989; McKinney 2002). However, results of this study show that urban areas are able to sustain various species of snakes. The abundance of several species indicates that these species are adaptive. The existence of snakes also depends on the availability of microhabitats in urban areas. For example, snakes in Bogor are far more diverse than other locations. Bogor has varied land cover in which settlement area are close to vegetated area, i.e. nearby plantation forest, dry land agricultural land, dry land mixed with bush land, and rice fields (Lidiawati et al. 2019). This allows various species of snakes that live in natural habitats to be accidentally found around settlements.

One of the problems with the diverse snake around the human settlements is the increase possibility of snake bite incidents. Occurrence of snake bite cases is often associated with human activities such as farming and gardening activities (WHO 2016). Indonesia only have one type of snake antivenom called serum anti bisa ular (SABU) which is a polyvalent drug for three common venomous species in western part of Indonesia: javan spitting cobra, banded krait, and malayan pit viper (WHO 2016). Unfortunately, SABU for other notable venomous snake species such as malayan krait, king cobra, and Trimeresurus sp is currently not available. Considering the high number of venomous snake encounters in residential areas and lack of public knowledge of prevention and first aid of venomous snake bites, snake bite cases in greater Jakarta Metropolitan Areas could increase in the future.

Of the eight organizations interviewed, almost all except Termites and Pest Control company, are voluntarily rescued snakes. Reptile communities are spread in each region, sometimes one community can rescue snakes across regions. For example, Tabu Indonesia who sat in Depok, will also rescues snakes from Bogor area if needed. The majority of reptile communities have the same goal, which is to mitigate conflicts between snakes and humans, prevent snakes from being killed by the community, prevent snakebite cases due to mishandling as part of their educational efforts to inform snakes to the public. Meanwhile, the Fire Departments work aims at community service, i.e. mitigate conflict between snakes and humans without the need to conserve or educating people.

Reptile communities have members with varied backgrounds, ranging from school children (elementary, junior high, high school), students from various majors, and employees. Not all members have educational background in biology, but they have interest in snakes as one of the motivations for learning. Some communities conduct regular basic internal training in handling snakes and snake bites, such as the Ciliwung
Herpetarium, Aspera Community, Indonesian Wagleri, Sioux, and the Fire Departments. There are also those who have participated in training conducted by other organizations. Sioux Indonesia is an organization that routinely conducts snake handling training, both for volunteers who want to join or for the general public. All organizations on average have the same procedure for snake rescue assistance. First, they will verify and giving direction or guidance through phone before coming to location and then sending their representative to capture the snake. Lastly, except for fire fighter, they will educate the community regarding snake in the area.

Pest and Termites Control, Central Jakarta Fire Department and three reptile communities (Ciliwung Herpetarium, Tabu Indonesia, Sioux) have a written standard operational procedures (SOP). For others, even though there is no written SOP, each member knows the proper equipment needed such as pouches, sticks, glasses (specifically for handling Javan spitting cobra) and boots, and the right techniques. Number of people needed during rescue operations depends on the species and location. For example, if relatively large snake such as reticulated python will require lot of extra energy. Almost all organizations stipulated at least two people during rescue operations, except for firefighters based on their SOP, a team will consist of six people.

Snake captured will be relocated to a place far from the residential areas. Some were released immediately, as was done by Pest and Termites Control officers. Some are taken to the pen to be quarantined first if the snake is injured, or will be released to a more distant location. The firefighters usually will contact reptile community to collect snake. Release sites are selected based on habitat suitability, prey availability, distance from water sources, and distance from residential areas. Some species that do not cause fatalities, such as non-venomous snakes, are released not far from the residential areas. However, venomous and large-sized snake are mostly released far from human settlements. The locations that become release sites are the Ciliwung or Cisadane river banks, Mount Malang, Mount Pancar, around Mount Halimun Salak National Park and Mount Gede Pangrango National Park, Mount Pancar, Mount Sindur, Tajur, and Ciputat.

The reptile organizations in Greater Jakarta Metropolitan Area served as a community for people with various backgrounds who have interest in reptiles. They all have a common goal to educate people and to change perception of snakes by increasing positive interactions between snakes and humans. This kind of been conducted in Brazil to minimize fear by increasing experiences or interaction with snake to reduce fear (Pinheiro et al. 2016). Therefore, socialization to the community after relocation becomes important as part of education to correct perceptions, reduce fear or trauma after meeting snakes around the house. However, the 
effectiveness of socialization depends on the knowledge capacity and communication skill of each member.

When relocating snakes, all communities have informally known what needs to be carried and worn to handle snakes safely. However, not all organizations have a written SOPs on snake handling and relocation management. Apart from the standard contents of the SOP document, having an SOP is important for every organization when carrying out activities. The SOP contains systematic standardized work procedures and is useful as a guideline for all members when relocating snakes effectively. Absence of SOPs can lead to miscommunication, increase the risk of dangerous events, and can interrupt the transfer of knowledge between members.

Snakes rescued are usually released. Pest and Termites Control does not implement a quarantine system for captured snakes to reduce the cost of expenditure. It is not clear whether the organization implementing the quarantine system is doing it properly or just temporarily storing the snake until it is released again. Only one community (Ciliwung Herpetarium) have a complete animal management SOP, including a quarantine SOP.

After quarantine, snakes are translocated to habitats that are far from residential areas, a common activity carried out to mitigate conflicts between animals and humans (Clemman et al. 2004). Some studies suggest that translocation over long distances (more than a few kilometers) can change the normal behaviour patterns of snakes (i.e. in Crotalus spp., Viperidae) and increase the risk of snake death (Reinert and Rupert 1999). In research on Notechis scutatus and Crotalus oreganus, translocation affects the behavior and spatial ecology of snakes by expanding the range and increasing movement (Heiken 2013). This will be a new problem if the snake is released in the forest that is still close to settlements. However, Heiken (2013) states that longdistance translocation in Crotalus oreganus does not indicate chronic stress or disruption of thermoregulation. It is likely that each species has a different response to translocation. The snakes most often translocated from settlements are highly venomous snakes (Naja sputatrix, Bungarus sp.) and Malayopython reticulatus. Little information is available about the effects of long-distance translocation on these species.

There is no evidence that the selection and assessment of habitat for snake released has been based on scientific methods. There is no evaluation of habitat conditions prior to release and evaluation of individual snakes after release, so it cannot be assessed whether the snakes survive or not. Previous studies have consistently shown low success rates for snake translocation (Brown et al. 2009; Kingsbury and Attum 2009; Lee and Park 2011; Nowak et al. 2002; Reinert \& Rupert 1999), although some are showing the success of translocation (Walker et al. 2009). A more thorough evaluation and plan are needed to assess the success of translocation, both in terms of conflict mitigation and conservation. To support efforts to mitigate the conflict between snakes and humans, further research is needed regarding the time pattern of snake encounters in settlements, the characteristics, behaviour and perceptions of people when meeting snakes in settlements, as well as the success rate of translocation and their impact on snake behaviour. Management of reptile habitat in urban areas also needed to conserve snakes. This is not the responsibility of only the community, but also collaboration from various parties, including government, research institutions, and other conservation institutions.

\section{CONCLUSION}

Snakes occurrences in Greater Jakarta Area, showed the ability of snake to adapt in urban areas. As Javan spitting cobra is one of the most common snake found, there is a need to prepare for the increase of snake bite incident. Snake relocation activities and education is a way to mitigate conflicts between humans and snakes. Not all organisations have standard SOP for snake rescue, including translocation activities that have considered ecological and conservation success.

\section{REFERENCES}

Brown JR, Bishop CA, Brooks RJ. 2009. Effectiveness of short-distance translocation and its effects on western rattlesnakes. Journal of Wildlife Management. 73: 419-425.

Ceríaco LM. 2012. Human attitudes towards herpetofauna: The influence of folklore and negative values on the conservation of amphibians and reptiles in Portugal. Journal of Ethnobiology and Ethnomedicine. 8 (1): 8.

Clemman N, McGee T, Odgers J. 2004. An insight into the management of snakes on private properties by snake controllers and first contact organizations in Melbourne, Australia. Human Dimensions of Wildlife. 9: 133-142.

Davies RG, Webber LM, Barnes GS. 2004. Urban wildlife management - it's as much about people!' in D. Lunney \& S. Burgin (eds). Urban Wildlife: More than meets the eye. Royal Zoological Society of New South Wales. Mosman. pp 38-43.

Fajar. 2018. Piton Raksasa Kembali Mangsa Manusia, Kali ini di Muna, in Fajar from https://www.fajar.co.id/2018/06/15/piton-raksasakembali-mangsa-manusia-kali-ini-di-muna/. October 2019].

Fakih F. 2019. Ular Sanca Sepanjang Tiga Meter Ditemukan di Jakarta Utara, in Merdeka, from https://www.merdeka.com/jakarta/ular-sancasepanjang-tiga-meter-ditemukan-di-jakartautara.html. [7 March 2019]. 
Gibbons J, Scott DE, Ryan TJ, Buhlmann KA, Tuberville TD, Metts BS, Greene JL, Mills T, Leiden Y, Poppy S, Winne C, 2000. The Global Decline of Reptiles, Deja Vu Amphibian. Bioscience. 50 (8): 653-666.

Gilbert OL. 1989. The Ecology of Urban Habitats. Chapman and Hall. New York.

Hartanto E. 2014. Studi penyebaran sub-ordo ophidian di Pulau Jawa dengan menggunakan aplikasi sistem informasi geospasial (SIG). BSc. Thesis. Departemen Konservasi Sumberdaya Hutan dan Ekowisata, Fakultas Kehutanan IPB. Bogor.

Heiken KH. 2013. The behavioural and physiological effects of long-distance translocation on western rattlesnakes (Crotalus oreganus). MSc. Thesis. Faculty of California Polytechnic State University. California.

Kingsbury BA, Attum O. 2009. Conservation strategies: captive rearing, translocation, and repatriation, in $\mathrm{SJ}$ Mullin \& RA Seigel (eds). Snakes: Ecology and Conservation. Cornell University Press. New York. Pp 201-220.

Knight AJ. 2008. "Bats, snakes and spiders, oh my!" how aesthetic and negativistic attitudes, and other concepts predict support for species protection. Journal of Environmental Psychology. 28 (1): 94103.

Kumar V, Maheshwari R, Verma HK. 2006. Toxicity and symptomatic identification of species involved in snakebites in the Indian subcontinent. Journal of Venomous Animals and Toxins including Tropical Diseases. 12 (1): 3-18.

Kusrini M, Palesa SP, Masy'ud B. 2021. Snake pet ownership in the city: A case study in Greater Jakarta, Indonesia. Biodiversitas Journal of Biological Diversity 22: 1790-1798.

Lee JH, Park D. 2011. Spatial ecology of translocated and resident amur ratsnakes (Elaphes chrenckii) in two mountain valleys of South Korea. Asian Herpetological Research. 2: 223-229.

Lidiawati I, Hasibuan R, Wijayanti R. 2019. Perubahan penggunaan lahan kota Bogor. Talenta Conference Series Agricultural and Natural Resources. 2 (1): 4451.

Longbottom J, Shearer FM, Devine M, Alcoba G, Chappuis F, Weiss DJ, Ray SE, Ray N, Warrell DA, Ruiz de Castañeda R, Williams DJ, Hay SI, Pigott DM. 2018. Vulnerability to snakebite envenoming: a global mapping of hotspots. The Lancet 392: 673684.

Maulana F. 2019. Ular Piton Ukuran 3 Meter Jatuh dari Kanopi Rumah Warga Pesanggrahan', in Detik https://news.detik.com/berita/d-4452522/ular-pitonukuran-3-meter-jatuh-dari-kanopi-rumah-wargapesanggrahan. [7 Marh 2019].

Maritz B, Alexander G J, Maritz R A. 2018. The underappreciated extent of cannibalism and ophiophagy in African cobras. Ecology Society of America. 100 (2): https://doi.org/10.1002/ecy.2522.

Maulidi A, Purnaningsih T, Maulina A, Gunawan YE, Rizki M. 2020. Short Communication: Herpetofauna diversity at the University of Palangka Raya, Indonesia. Biodiversitas Journal of Biological Diversity 21: 4509-4514.

McKinney ML. 2002. Urbanization, biodiversity, and conservation. BioScience. 52: 883-890.

McKinney ML. 2008. Effects of urbanization on species richness: a review of plants and animals. Urban Ecosystem. 11: 161-176.

Neke D. 2019. Piton Memangsa Manusia Terjadi Lagi, Wa Sogo Tewas Diterkam dan Dililit Piton 7 Meter, Kronologinya', in Tribunnews. https://www.medan.tribunnews.com/2019/06/06/pito n-memangsa-manusia-terjadi-lagi-wa-sogo-tewasditerkam-dililit-piton-7-meter-kronologinya?page $=4$. [October 6, 2019].

Nowak EM, Hare T, McNally J. 2002. Management of "nuisance" vipers: effects of translocation on western diamond-backed rattlesnakes (Crotalus atrox)' in G. W. Schuett G.W., O'Shea M (eds). Venomous snakes of the world. Princeton University Press. New Holland. pp. 525-552.

Öhman A, Mineka S. 2003. The malicious serpent: snakes as a prototypical stimulus for an evolved module of fear. Current Directions in Psychological Science. 12 (1): 5-9.

Pinheiro L T, Rodrigues J F M, Nojosa D M B. 2016. Formal education, previous interaction and perception influence the attitudes of people toward the conservation of snakes in a large urban center of northeastern Brazil. Journal of Ethnobiology and Ethnomedicine. 12: 25.

Reed RN, Krysko KL. 2013. Invasive and introduced reptiles and amphibians. Current Therapy in Reptile Medicine and Surgery. 28: 304-309.

Reinert HK, Rupert RR. 1999. Impacts of translocation on behaviour and survival of timber rattlesnakes, Crotalus borridus. Journal of Herpetology. 33: 4561.

Roshnath R. 2017. Snake rescues; a conservation effort in Kannur district. Kongunadu Reseach Journal. 4 (1): 161-165.

Rusli N. 2016. Mengenal Ular Jabodetabek. Bypass. Bogor.

Shankar PG, Ganesh SR, Whitaker R, Prashanth P. 2013. King Cobra Ophiophagus hannah (Cantor, 1836) encounters in human-modified rainforests of the Western Ghats, India. Hamadryad 36: 62-68.

Shine R, Koenig J. 2001. Snakes in the garden: an analysis of reptiles "rescued" by community-based wildlife carers. Biological Conservation. 102 (2001): 271-283.

Stuart B, Thy N, Chan-Ard T, Nguyen T Q, Grismer L, Auliya M, Das I, Wogan G. 2018. 'Python 
reticulatus', in The IUCN Red List of Threatened Species 2018: e.T183151A1730027, from https://dx.doi.org/10.2305/IUCN.UK.20182.RLTS.T183151A1730027.en. [11 February 2021].

Stuart B, Wogan, G, Grismer L, Auliya M, Inger RF, Lilley R, Chan-Ard T, Thy, N, Nguyen TQ, Srinivasulu C, Jelić D. 2012. Ophiophagus hannah. The IUCN Red List of Threatened Species 2012: e.T177540A1491874. http://dx.doi.org/10.2305/IUCN.UK.20121.RLTS.T177540A1491874.en. [11 December 2021].

Uetz P, Stylianou A. 2018. The original descriptions of reptiles and their subspecies. Zootaxa. 4375: 257264.
Walker ML, Dorr JA, Benjamin RJ, Pisani GR. 2009. Successful relocation of a threatened suburban population of timber rattlesnakes (Crotalus borridus): combining snake ecology, politics, and education. IRCF Reptiles and Amphibians. 16: 210-221.

[WHO] World Health Organization. 2016. Guidelines for the management of snakebites. India: World Health Organization.

Yue S, Bonebrake TC, Gibson L. 2019. Human-snake Conflict Patterns in a Dense Urban-Forest Mosaic Landscape. Herpetological Conservation and Biology. 14: 143-154 